\title{
Kidney pathology and parasite intensity in rainbow trout Oncorhynchus mykiss surviving proliferative kidney disease: time course and influence of temperature
}

\author{
Heike Schmidt-Posthaus ${ }^{* * *}$, Kathrin Bettge ${ }^{* *}$, Ursula Forster, Helmut Segner, \\ Thomas Wahli
}

Centre for Fish and Wildlife Health, Department of Pathobiology, University of Berne, Laenggassstrasse 122, PO Box 8466, 3001 Berne, Switzerland

\begin{abstract}
Proliferative kidney disease (PKD) is an endoparasitic disease of salmonids caused by the myxozoan parasite Tetracapsuloides bryosalmonae. We recently described the development of the disease from initial infection until manifestation of clinical disease signs in rainbow trout held at 2 water temperatures, 12 and $18^{\circ} \mathrm{C}$. The aim of the present study is to investigate whether (1) infected fish surviving the clinical phase would recover from renal pathological changes, (2) whether they would be able to reduce the parasite load in the kidneys, and (3) whether water temperatures would influence renal recovery and parasite clearance. At $18^{\circ} \mathrm{C}$, fish showed a gradual recovery of normal kidney morphology which was associated with a decline in parasite numbers and infection prevalence. Fish kept at $12^{\circ} \mathrm{C}$ initially showed an enhancement of kidney lesions before recovery of normal kidney morphology took place. The decrease in renal parasite load was retarded compared to $18^{\circ} \mathrm{C}$. The results from the present study provide evidence that rainbow trout surviving the clinical phase of PKD are able to (1) fully restore renal structure, and (2) significantly reduce renal parasite loads, although $100 \%$ clearance was not achieved within the experimental period of this study. Water temperature influences the rate but not the outcome of the recovery process.
\end{abstract}

KEY WORDS: Tetracapsuloides bryosalmonae - Proliferative kidney disease · Temperature · Post-clinical phase $\cdot$ Histopathology $\cdot$ Parasite numbers

\section{INTRODUCTION}

Proliferative kidney disease (PKD) is a parasitic infection of salmonids caused by Tetracapsuloides bryosalmonae (Myxozoa: Malacosporea) (Hedrick et al. 1993, Canning et al. 2000, Okamura et al. 2001). The parasite life-cycle, as currently understood, includes bryozoans as invertebrate hosts (Anderson et al. 1999, Longshaw et al. 1999, Okamura et al. 2001) and salmonids as vertebrate hosts (Feist \& Bucke 1993, Hedrick et al. 1993). T. bryosalmonae infects fish through skin and gills (Feist et al. 2001, Longshaw et al. 2002) and after invasion is distributed systemically via the blood stream. The main target organ is the kidney (Kent \& Hedrick 1985) where T. bryosalmonae undergoes multiplication and differentiation from extrasporogonic to sporogonic stages (Kent \& Hedrick 1985). Infected salmonids can excrete spores via the urine (Kent \& Hedrick 1985, Morris et al. 2002, Hedrick et al. 2004, Bettge et al. 2009a,b) and transmission of the parasite from fish to bryozoans via excreted spores has been shown for brown trout Salmo trutta and brook trout Salvelinus fontinalis (Morris \& Adams 2006, Grabner \& ElMatbouli 2008). 
Bettge et al. (2009a,b) characterized parasite proliferation and kidney pathology in the fish host, from initial infection to the clinical phase of the disease. In rainbow trout Oncorhynchus mykiss reared at $18^{\circ} \mathrm{C}$, the concentration of parasites and parasite DNA in the kidney increased exponentially from initial infection until it reached a plateau level at approximately 26 d post exposure (p.e.). This plateau was maintained until the end of the experiment at Day 47 p.e. In parallel to the increase of renal parasite load, renal swelling and anemia developed (Bettge et al. 2009a). Histologically, this was accompanied by a proliferative and granulomatous nephritis and a necrotizing vasculitis with thrombus formation (Bettge et al. 2009a). Furthermore, cumulative mortality among infected trout kept at $18^{\circ} \mathrm{C}$ steadily increased during the infection and reached $77 \%$ at Day 47 p.e.

The severity of clinical signs and lesions as well as the associated mortalities of Tetracapsuloides bryosalmonae-infected fish appeared to be temperature dependent (Bettge et al. 2009a). Specifically, rainbow trout infected with $T$. bryosalmonae and kept at $12^{\circ} \mathrm{C}$ water temperature developed less severe clinical disease signs and less severe renal pathological changes than fish kept at $18^{\circ} \mathrm{C}$ (Bettge et al. 2009b). In addition, cumulative mortality did not surpass $6 \%$ within the $47 \mathrm{~d}$ experimental period, in contrast to the $77 \%$ mortality of trout reared at $18^{\circ} \mathrm{C}$. Interestingly, while the rate of increase of parasite DNA was clearly retarded at the lower water temperature when compared to that of trout kept at $18^{\circ} \mathrm{C}$, maximum concentration of parasite DNA in the kidneys of $12^{\circ} \mathrm{C}$ trout was only moderately lower (Bettge et al. 2009b).

In trout reared at $18^{\circ} \mathrm{C}$, the intensity of clinical disease signs, the severity of renal histological lesions as well as parasite intensity had shown no further enhancement from Day 26 onwards until the end of the experiment at $47 \mathrm{~d}$ p.e., while cumulative mortality was still increasing. This leads to the question of whether the plateau phase of the clinical and pathological parameters indicates a turning point in the disease, and whether such recovery would be accompanied by parasite clearance from the host. The available literature suggests that recovery from the kidney lesions is possible (Ferguson 1981, Kent \& Hedrick 1985, Clifton-Hadley et al. 1987, Chilmonczyk et al. 2002, Morris et al. 2005). However, a systematic study on the temporal sequence of tissue repair and/or on the fate of the parasite in the host kidney has not been published to date. In addition, although water temperature has a major influence on the development of clinical disease (Bettge et al. 2009a,b), its possible role in the recovery process has not yet been studied.

The aim of the present study was to investigate mortality, renal histopathology and renal parasite load in rainbow trout infected with Tetracapsuloides bryosalmonae, starting from the clinical phase of PKD onwards, with regards to survival and the progress of renal histopathology, parasite load and distribution in the kidneys. In order to evaluate the role of water temperature on the recovery process, fish were kept at both 18 and $12^{\circ} \mathrm{C}$.

\section{MATERIALS AND METHODS}

\section{Experimental exposure and sampling}

Fish used for the present study originated from a former experiment in which 420 naive $0+$ rainbow trout Oncorhynchus mykiss were infected by exposing the fish to water from a Tetracapsuloides bryosalmonae-carrying river (Bettge et al. 2009a,b). After $5 \mathrm{~d}$ of exposure, infection of the exposed fish had reached $100 \%$ prevalence ( $n=20$ ), as demonstrated by means of real-time PCR on $T$. bryosalmonae DNA in the fish kidney. Thereafter, 400 infected fish were transferred into the laboratory and kept in $T$. bryosalmonae-free tap water. The fish were subdivided into 2 groups and kept at 12 and $18^{\circ} \mathrm{C}(\mathrm{n} \approx 200$ per temperature). At Day 47 post exposure (p.e.), fish kept at $18^{\circ} \mathrm{C}$ had reached a plateau phase of clinical disease signs, renal parasite concentrations and renal histopathology (Bettge et al. 2009a) (see Table 1 for summary of lesions, see also Figs. 1 \& 4). For the present study, fish surviving this clinical phase of PKD $\left(18^{\circ} \mathrm{C}: 42\right.$ fish; $12^{\circ} \mathrm{C}: 151$ fish $)$ were maintained at the respective temperatures, and sampled to examine the further progress of the disease. An initial sampling of 10 animals was made at Day 47 p.e. The remaining 32 fish in the $18^{\circ} \mathrm{C}$ group were maintained for another $84 \mathrm{~d}$ (until Day 131 p.e.) and the remaining 141 fish in the $12^{\circ} \mathrm{C}$ group for 154 d (until Day 201 p.e.). The initial sampling of 10 fish from both groups $\left(12\right.$ and $\left.18^{\circ} \mathrm{C}\right)$ at $47 \mathrm{~d}$ p.e., was followed by 3 further samplings of 4 to 10 fish in the $18^{\circ} \mathrm{C}$ group $(75,103,131 \mathrm{~d}$ p.e. $)$, and 5 samplings of 10 fish in the $12^{\circ} \mathrm{C}$ group $(75,103,131,159$ and $201 \mathrm{~d}$ p.e.) (see Table 1).

Fish were kept as described by Bettge et al. (2009a). Mortalities were recorded daily, and fish dying between the sampling days were necropsied and investigated parasitologically as described below. 
Sampled fish were euthanized in buffered 3aminobenzoic acid ethyl ester (MS 222 ${ }^{\circledR}$, Argent Chemical Laboratories). Length (L) and weight (W) were recorded and a condition factor calculated $\left(\mathrm{WL}^{-3}\right.$ $\times 100$ ). A standard necropsy was performed on all fish.

Five fish per sample (if available) were examined for the presence of parasites other than Tetracapsuloides bryosalmonae by microscopical evaluation of fresh mounts from the skin, the gills and the intestinal content. Fish were dissected and assessed for macroscopic changes typical of a PKD infection, such as darkening of skin, exophthalmia, pale gills, kidney swelling or ascites. The degree of kidney swelling was graded as 0 (none), 1 (scattered), 2 (mild), 3 (mild to moderate), 4 (moderate), 5 (moderate to severe) or 6 (severe). The kidneys were removed and cut along the longitudinal axis into 2 equal parts. One half was frozen in liquid nitrogen for PCR analysis, while the other half was fixed in $10 \%$ buffered formalin for histopathology, immunohistochemical staining (IHC) and in situ hybridisation (ISH).

To analyze fish urine for the presence of Tetracapsuloides bryosalmonae, 5 fish of each group were held for 30 min before euthanasia in 21 tanks containing tap water. It was assumed that salmonid fish release urine approximately every $30 \mathrm{~min}$ (Curtis \& Wood 1991). After removing the fish, the water was filtered through a 4-12 $\mu \mathrm{m}$ filter paper mesh (Schleicher \& Schuell MicroScience). The filters were stored at $-20^{\circ} \mathrm{C}$ until further analysis.

\section{Histopathology, IHC and ISH}

Formalin-fixed kidney samples were paraffinembedded and routinely processed for histological examination. Three consecutive sections of $3 \mu \mathrm{m}$ thickness were prepared for histopathology (haematoxylin-eosin stain, H\&E), IHC using a monoclonal anti-Tetracapsuloides bryosalmonae (PKX) antibody (AquaMAb-P01, Aquatic Diagnostics) (Adams et al. 1992) and ISH for T. bryosalmonae using digoxigenin-labeled probes according to Longshaw et al. (2002) and Bettge et al. (2009a). Histopathological lesions were graded 0 to 6 as for the degree of kidney swelling. Developing nephrons (nephron neogenesis) were classified according to Watanabe et al. (2009), whereby relatively small condensed basophilic cell clusters consisting of both mesenchymal condensate and nephrogenic bodies were considered as developing nephrons.

Six microscopic fields $(160 \times)$ per IHC and ISH treated slide were randomly selected and the num- ber of parasites per field counted at different organ locations (renal interstitial tissue, vessels, tubules). For each time point the mean value for all examined fish per temperature group was calculated.

\section{Real-time PCR for detection of parasite DNA in kidney tissue and fish urine}

Total DNA of rainbow trout kidneys was extracted from frozen kidney tissue with DNAzol (Lucerna) according to the manufacturer's protocol. For extracting genomic DNA from the fish urine the uppermost layer of the stored filters was removed with a scalpel blade and the total DNA extracted from this material using DNAzol. Real-time PCR was performed according to the method described by Bettge et al. (2009b).

\section{Statistical analysis}

The cumulative mortality was defined as the number of fish that died during the experiment. Significant differences between the 2 groups were tested using the $\chi^{2}$ test at a $\mathrm{p} \leq 0.05$ significance level. The condition indexes of the fish were analysed using Student's $t$-test. The amounts of parasite DNA as determined by real-time PCR were tested for normal distribution with the Skewness, Kurtosis and Omnibus Normality tests, and then compared and tested for significant differences using a 2-way ANOVA with the Tukey Kramer test as follow-up. The results of the IHC and ISH counts from each group were compared at every sampling point. As the values were not normally distributed, significant differences were tested using the Mann-Whitney $U$ or Wilcoxon Rank-Sum test with a $\mathrm{p} \leq 0.05$ significance level. The results were also assessed for differences between the quantitative real-time PCR, IHC and ISH counting methods using the Spearman rank correlation. For all statistical tests, NCSS 2001 (Hintze 2006) was used.

\section{RESULTS}

\section{Mortality}

After the start of the present experiment (47 d p.e.), a mortality of 11 fish occurred during the first $15 \mathrm{~d}$ in the $18^{\circ} \mathrm{C}$ group $(\mathrm{n}=32)$, with no further mortalities thereafter. In the $12^{\circ} \mathrm{C}$ group $(\mathrm{n}=141)$ the mortality 
was significantly lower (3 fish) and was restricted to the first week (47-54 d p.e.) of the experiment.

\section{Condition index}

In both groups (18 and $\left.12^{\circ} \mathrm{C}\right)$, condition indexes of individual fish varied from 0.9 to 1.4 throughout the experiment. No significant differences were observed, neither between sampling points nor temperature groups (data not shown).

\section{Infection prevalence}

In the $18^{\circ} \mathrm{C}$ group, the prevalence of animals positive for Tetracapsuloides bryosalmonae DNA, as determined by real-time PCR, dropped from 100\% at $47 \mathrm{~d}$ p.e. to $25 \%$ at the end of the experiment (131 d p.e.). In the $12^{\circ} \mathrm{C}$ group, prevalence of positive animals dropped from $100 \%$ at 47 d p.e. to $20 \%$ at Day 131 p.e., and to $11 \%$ at the end of the experiment (Day 201 p.e.).

\section{Concentrations of parasites and parasite DNA in fish kidney and urine}

$18^{\circ} \mathrm{C}$ group. Quantitative PCR showed a gradual decline in parasite DNA copy numbers per gram of kidney tissue over time (Fig. 1). This decline was significant between 47 and 75 d p.e.; 2-way ANOVA showed that the copy numbers of Days 75 and 103 both differed significantly from those of Day 47. At 131 d p.e., in the only positive fish, $2.57 \times 10^{3}$ copy numbers were found. The decline in parasite DNA was exponential $\left(\mathrm{r}^{2}=0.894\right)$.

Using IHC and ISH, the number of Tetracapsuloides bryosalmonae in the kidneys decreased significantly between 47 and 75 d p.e. (Fig. 2a). From 103 d p.e. onwards no parasites were detected, apart from a single parasite detected by ISH in the interstitium of 1 fish at 131 d p.e. At 47 d p.e., the infection was most intense in the kidney interstitium while in the other organ compartments only a limited number of parasites were present (Figs. 2a \& 3, Table A1 in Appendix 1). Parasites were detectable by IHC in the renal interstitium until 75 d p.e., while in kidney blood vessels and renal tubules, no parasites were found after $47 \mathrm{~d}$ p.e. (Fig. 2a, Table A1). The results from ISH and IHC were comparable with respect to the time-dependent changes of parasite numbers in the 3 renal compartments (Fig. 2a). At 47 d p.e., there were significantly more parasites detectable in the renal interstitium by ISH compared to IHC (Fig. 2a). In the urine, parasite DNA was detected only at $47 \mathrm{~d}$ p.e.

$12^{\circ} \mathrm{C}$ group. Copy numbers of parasite DNA gradually declined with time, from $4.82 \times 10^{5}$ (mean value from 9 to 10 animals) at Day 47 p.e. to $5.74 \times 10^{2}$ in the single positive fish found in the last sampling at 201 d p.e. (Fig. 1). The parasite DNA decline in the $12^{\circ} \mathrm{C}$ group followed an exponential curve $\left(\mathrm{r}^{2}=\right.$ 0.879 ) and seemed to be slower than in the $18^{\circ} \mathrm{C}$ group. Two-way ANOVA showed a significant difference between the copy numbers of Day 159 and those of Days 47 and 75.

Between-group differences in renal parasite DNA concentrations between 18 and $12^{\circ} \mathrm{C}$ were nonsignificant at all sampling time points (Fig. 1) and 2way ANOVA revealed no interaction between both treatments.

By counting the parasites in the kidney using IHC and ISH, the highest parasite numbers were again found in the interstitium, whereas renal blood vessels and tubules displayed only low numbers of parasites (Fig. 2b). The number of parasites showed no significant change between 47 and 103 d p.e., and after 103 d p.e. parasites were no longer detected in the histological sections. In comparison to the $18^{\circ} \mathrm{C}$ group, the $12^{\circ} \mathrm{C}$ group showed significantly lower parasite numbers in the interstitium at $47 \mathrm{~d}$ p.e. (Fig. 3), but not at any later time point (Table A1). Similarly to the $18^{\circ} \mathrm{C}$ group, parasite DNA in the urine of $12^{\circ} \mathrm{C}$ fish was detected only at $47 \mathrm{~d}$ p.e.

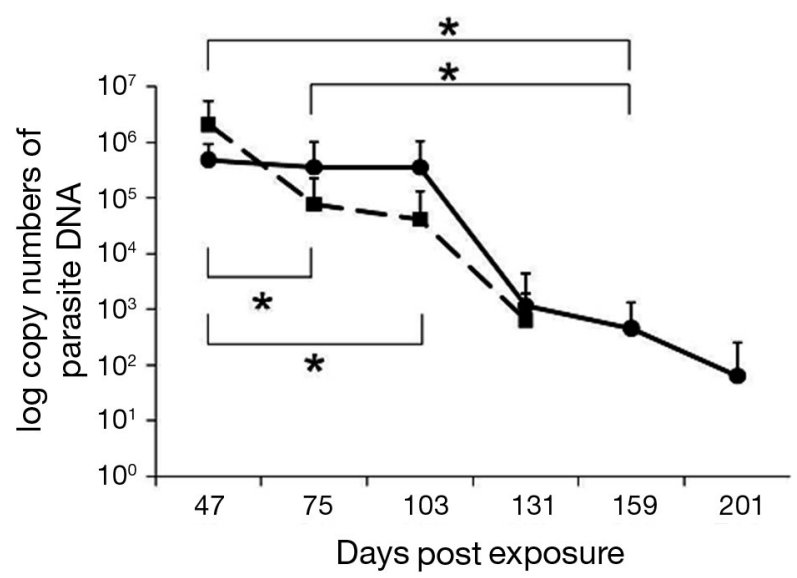

Fig. 1. Intensity of infection as estimated from PCR detection of Tetracapsuloides bryosalmonae DNA in kidneys of infected rainbow trout Oncorhynchus mykiss, showing the mean $(+\mathrm{SD})$ copy numbers of parasite DNA per $2 \mu \mathrm{g}$ of total DNA. Dashed line: $18^{\circ} \mathrm{C}$ group; solid line: $12^{\circ} \mathrm{C}$ group. Asterisks indicate significant differences between samples $\left(\mathrm{p} \leq 0.05\right.$ ) in the $18^{\circ} \mathrm{C}$ group (below) and in the $12^{\circ} \mathrm{C}$ group (above) 


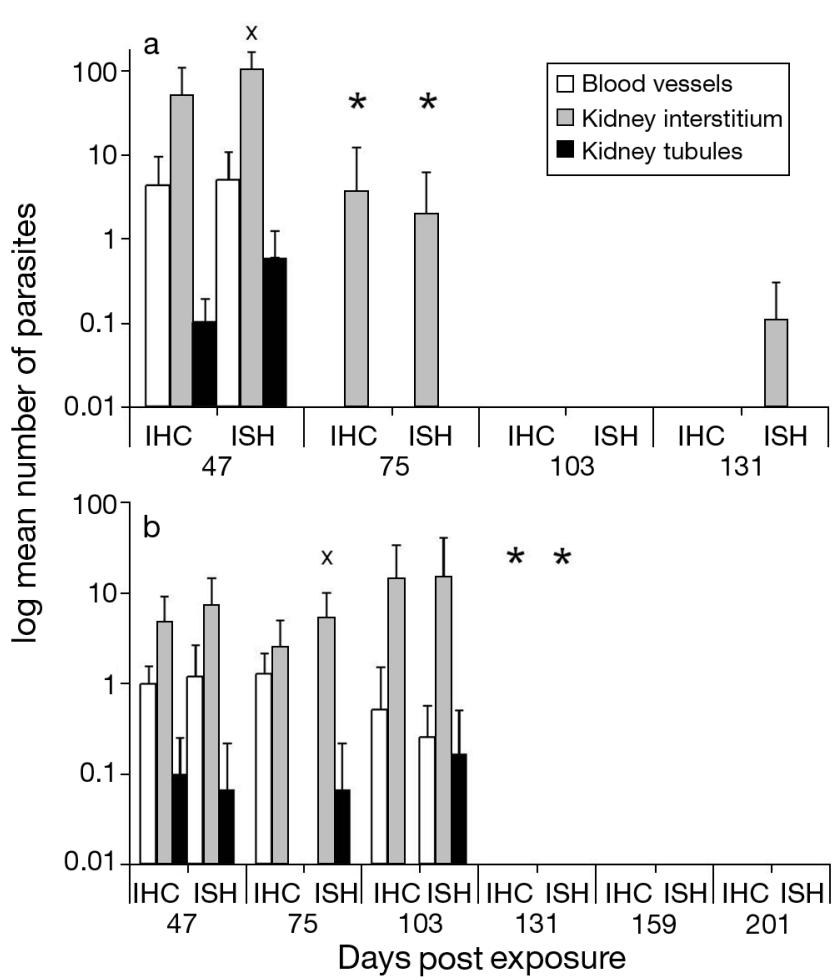

Fig. 2. Numbers of Tetracapsuloides bryosalmonae (logarithmic mean $+\mathrm{SD}$ ) in 3 kidney compartments of rainbow trout Oncorhynchus mykiss held at (a) $18^{\circ} \mathrm{C}$ and (b) $12^{\circ} \mathrm{C}$, estimated using immunohistochemical staining (IHC) and in situ hybridization (ISH). Significant differences ( $\mathrm{p} \leq 0.05)$ are shown between consecutive samples $(*)$ and the 2 methods used $(\mathrm{x})$

\section{Renal pathology}

$1^{\circ} \mathbf{C}$ group. The prevalence of fish showing kidney swelling dropped from $100 \%$ at $47 \mathrm{~d}$ p.e. to $60 \%$ at $75 \mathrm{~d}$ p.e., while at 103 and $131 \mathrm{~d}$ p.e., kidneys of all fish appeared macroscopically normal (Table 1). Histologically, the extent of severity of renal proliferative and degenerative changes such as interstitial proliferation and necrosis, as well as fibrosis of interstitial tissue, decreased from 47 to $75 \mathrm{~d}$ p.e. (Figs. 4a,b \& 5a, Table A2 in Appendix 1). Degenerating parasites, characterized by hypereosinophilia and fragmentation of parasite cells and nuclei, were present in the interstitium at 47 and $75 \mathrm{~d}$ p.e. From 103 d p.e. onwards, no histopathological lesions were detectable in the kidneys. At 103 d p.e., some specimens examined showed an increase in the number of newly formed renal tubules, characterized by basophilic cell clusters with numerous mitotic figures, indicating nephron neogenesis (Fig. 5c).

$12^{\circ} \mathrm{C}$ group. Prevalence of fish displaying macroscopic signs of PKD decreased continuously over the experimental period and at the last 2 sampling points no fish showed clinical symptoms (Table 1). The extent of the macroscopic lesions increased until 103 d p.e. (severe kidney swelling in several animals) and subsequently decreased. Only mild lesions were observed in all cases at $131 \mathrm{~d}$ p.e. and none at later sampling points.

Table 1. Presence and effects of Tetracapsuloides bryosalmonae in kidneys of rainbow trout Oncorhynchus mykiss held at 18 and $12^{\circ} \mathrm{C}$, evaluated by means of macroscopic evaluation, real-time PCR, immunohistochemical staining (IHC), in situ hybridization (ISH) and histological examination of kidneys. IP: Infection prevalence. Severity of macroscopic changes is given as the mean value of kidney swelling indices of the individual fishes examined during necropsy and (in parentheses) lowest and highest values per sampling. Severity of the histological changes is given as mean value calculated from the histopathological indices of the individual fishes. Detailed data are shown in Tables A1 \& A2

\begin{tabular}{|c|c|c|c|c|c|c|c|c|c|c|}
\hline & \multicolumn{2}{|c|}{ Day 47} & \multicolumn{2}{|c|}{ Day 75} & \multicolumn{2}{|c|}{ Day 103} & \multicolumn{2}{|c|}{ Day 131} & \multirow{2}{*}{$\begin{array}{c}\text { Day } 159 \\
12^{\circ} \mathrm{C}\end{array}$} & \multirow{2}{*}{$\begin{array}{c}\text { Day } 201 \\
12^{\circ} \mathrm{C}\end{array}$} \\
\hline & $18^{\circ} \mathrm{C}$ & $12^{\circ} \mathrm{C}$ & $18^{\circ} \mathrm{C}$ & $12^{\circ} \mathrm{C}$ & $18^{\circ} \mathrm{C}$ & $12^{\circ} \mathrm{C}$ & $18^{\circ} \mathrm{C}$ & $12^{\circ} \mathrm{C}$ & & \\
\hline \multicolumn{11}{|c|}{ Macroscopic swelling of the kidneys } \\
\hline $\mathrm{N}$ & 10 & 10 & 5 & 10 & 5 & 10 & 5 & 10 & 10 & 10 \\
\hline Percentage $(\%)$ & 100 & 90 & 60 & 60 & 0 & 60 & 0 & 10 & 0 & 0 \\
\hline Mean severity & $5(4-6)$ & $3(0-4)$ & $3(0-4)$ & $4(0-6)$ & $0(0-0)$ & $4(0-6)$ & $0(0-0)$ & $0(0-2)$ & $0(0-0)$ & $0(0-0)$ \\
\hline \multicolumn{11}{|c|}{ Real-time PCR on $T$. bryosalmonae DNA } \\
\hline $\mathrm{N}$ & 10 & 10 & 5 & 10 & 5 & 10 & 4 & 10 & 9 & 9 \\
\hline IP (\%) & 100 & 100 & 100 & 100 & 100 & 90 & 25 & 20 & 44.4 & 11.1 \\
\hline \multicolumn{11}{|c|}{ IHC of $T$. bryosalmonae } \\
\hline $\mathrm{N}$ & 5 & 5 & 5 & 5 & 2 & 4 & 3 & 5 & 5 & 5 \\
\hline IP (\%) & 80 & 100 & 20 & 100 & 0 & 75 & 0 & 0 & 0 & 0 \\
\hline \multicolumn{11}{|c|}{ ISH of $T$. bryosalmonae } \\
\hline $\mathrm{N}$ & 5 & 5 & 5 & 5 & 2 & 4 & 3 & 5 & 5 & 5 \\
\hline IP (\%) & 100 & 100 & 40 & 100 & 0 & 75 & 33 & 0 & 0 & 0 \\
\hline \multicolumn{11}{|c|}{ Histological changes to the kidneys } \\
\hline $\mathrm{N}$ & 5 & 5 & 5 & 5 & 2 & 5 & 3 & 5 & 5 & 5 \\
\hline Percentage $(\%)$ & 100 & 100 & 80 & 100 & 100 & 100 & 0 & 60 & 100 & 0 \\
\hline Mean severity & 2.8 & 0.7 & 1 & 1.1 & 0.2 & 2.8 & 0 & 0.2 & 0.5 & 0 \\
\hline
\end{tabular}




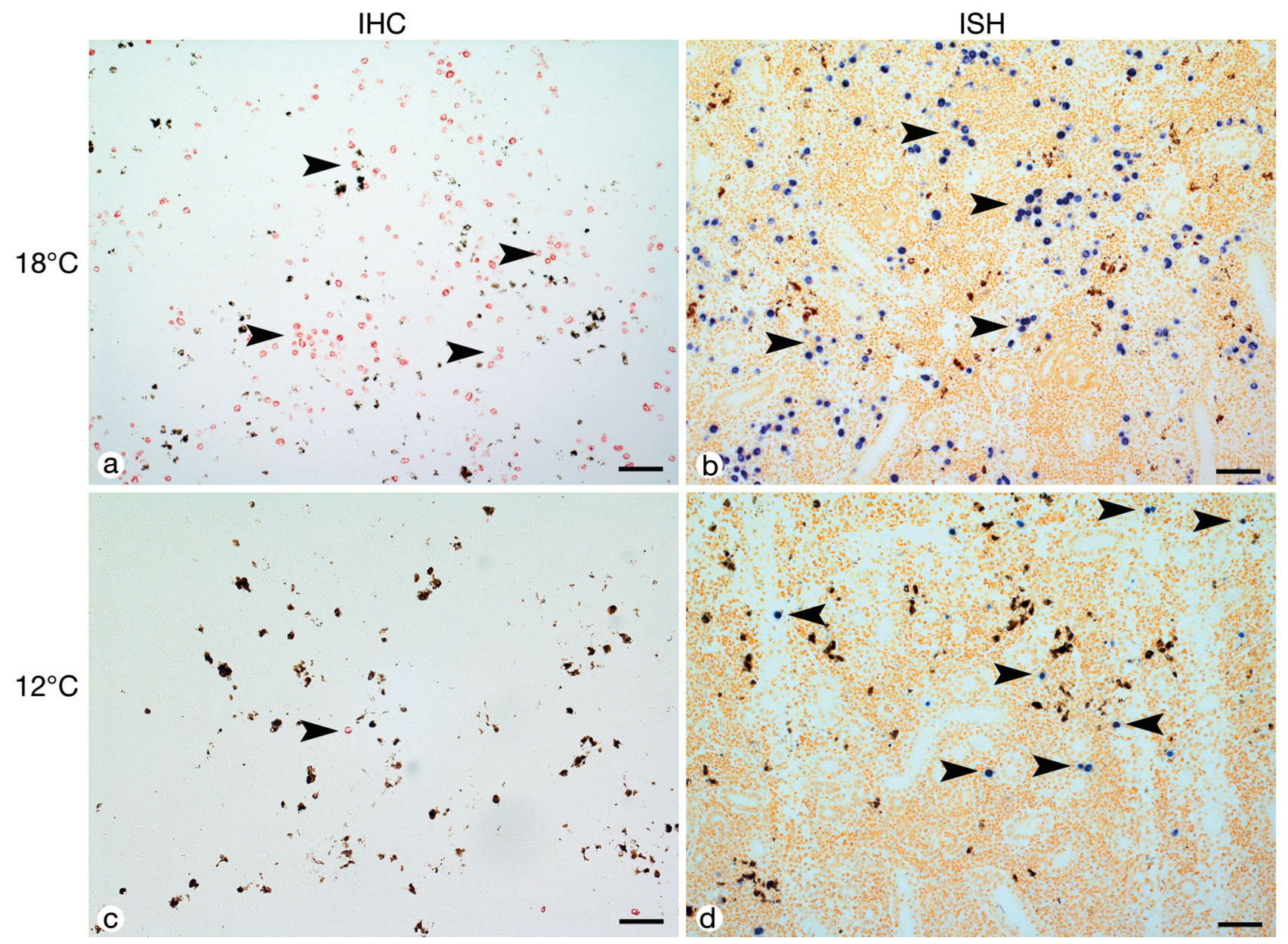

Fig. 3. Presence of Tetracapsuloides bryosalmonae in the kidney interstitium of rainbow trout Oncorhynchus mykiss at $47 \mathrm{~d}$ post exposure, shown by immunohistochemical staining (IHC) and in situ hybridization (ISH). (a) IHC and (b) ISH show high numbers of parasites in fish kept at $18^{\circ} \mathrm{C}$. (c) IHC and (d) ISH show small numbers of parasites in fish kept at $12^{\circ} \mathrm{C}$. Black arrowheads indicate single parasites. Scale bars $=50 \mu \mathrm{m}$

The prevalence of animals with histological lesions remained high until 159 d p.e. but at 201 d p.e. lesions were no longer detected. Histological kidney lesions increased slightly in the beginning of the experiment (Fig. 4c), reaching a peak at 103 d p.e. At this time point, a marked proliferative and granulomatous nephritis associated with necrotizing vasculitis, vascular thrombosis, scattered hemorrhage and multiple areas of necrosis were present in most of the affected animals (Fig. 5b,d, Table A2). In contrast, at 131 and 159 d p.e., only mild lesions were visible. Intralesional parasites were present both in the interstitium and in renal blood vessels until $103 \mathrm{~d}$ p.e. From the start of the experiment, interstitial parasites showed signs of degeneration and were surrounded by macrophages.

At 131 and 159 d p.e. proliferation and infiltration in the interstitium were replaced by fibrosis. In- creased numbers of developing nephrons (nephron neogenesis) were detectable from $103 \mathrm{~d}$ p.e. onwards (Fig. 5e, Table A2). At the last sampling point (201 d p.e.), normal kidney structure was restored in all investigated animals and no pathological changes were detected.

\section{Comparison between the different methods}

To evaluate whether changes of parasite DNA copy numbers measured by real-time PCR correlate with changes in parasite numbers as seen on IHC and ISH sections, the PCR samples were compared to results for the same individuals obtained using IHC and ISH. For fish held at $12^{\circ} \mathrm{C}$, there were linear correlations between PCR and IHC results, with a correlation coefficient of $\mathrm{r}^{2}=0.7167$, and between PCR and ISH 


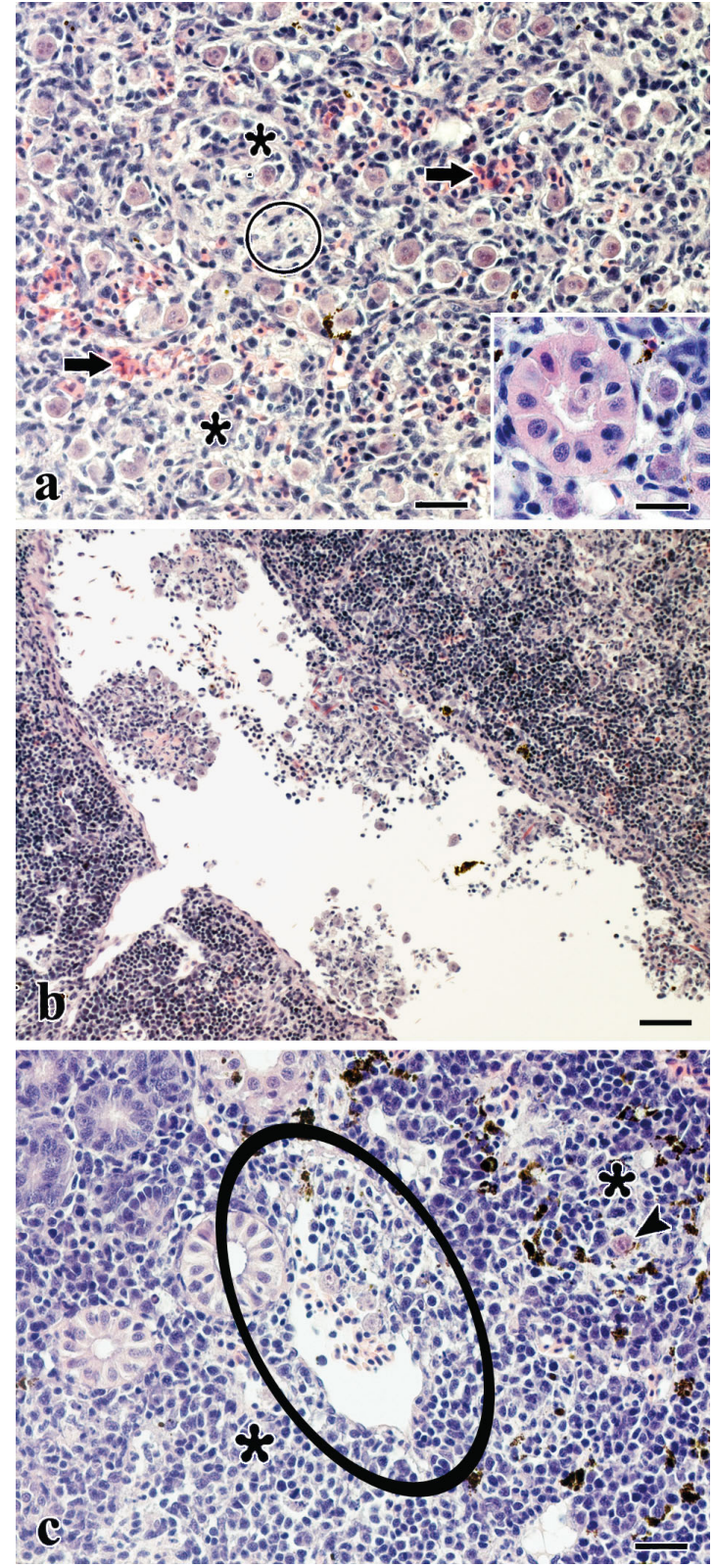

Fig. 4. Tetracapsuloides bryosalmonae in kidneys of rainbow trout Oncorhynchus mykiss, showing histological changes and parasite localization in fish held at $(\mathrm{a}, \mathrm{b}) 18^{\circ} \mathrm{C}$ and (c) $12^{\circ} \mathrm{C}$ at $47 \mathrm{~d}$ post exposure. (a) The kidney interstitium is severely expanded mainly as a result of infiltration by macrophages $(*)$, with the presence of necrotic cell debris (circle), hemorrhages (arrows) and parasites. Inset: Parasites extruding from the epithelium into the lumen of a renal tubule. (b) Renal blood vessel with multiple thrombi consisting of inflammatory cells (macrophages, lymphocytes and plasma cells; often degenerated), cell debris and parasites. (c) Renal blood vessel with thrombus consisting of macrophages, lymphocytes, plasma cells and parasites (inside circle). The renal interstitial tissue is proliferated and contains scattered $T$. bryosalmonae (black arrowhead) and mild infiltration with macrophages $(*)$ in the interstitium. H\&E staining. Scale bars $=(\mathrm{a}$,inset,c) $25 \mu \mathrm{m}$; (b) $50 \mu \mathrm{m}$ results, with $\mathrm{r}^{2}=0.9283$. In contrast, in fish with immunohistochemically intense infections ( $>50$ parasites per microscopic slide, as seen in the $18^{\circ} \mathrm{C}$ group), no correlation between PCR results and parasite counts was found $\left(\mathrm{r}^{2}=0.0535\right)$. Similarly, there was no correlation between PCR results and those obtained from ISH-stained sections in the $18^{\circ} \mathrm{C}$ group $\left(\mathrm{r}^{2}=0.1453\right)$.

\section{DISCUSSION}

The present study examined the progress of mortality, parasite infection and renal pathology of Tetracapsuloides bryosalmonae-infected rainbow trout after the clinical disease stage of PKD. Bettge et al. $(2009 \mathrm{a}, \mathrm{b})$ showed that, for trout kept at $18^{\circ} \mathrm{C}$, no further enhancement of clinical disease signs, no increase in the severity of histopathological lesions and no further elevation of renal parasite loads occurred between 21 and 47 d p.e. Apparently, the disease severity had reached a kind of plateau. In contrast, mortality continued to increase from 21 to 47 d p.e., reaching $77 \%$ on Day 47 . However, in the phase after $47 \mathrm{~d}$ p.e., which is investigated in the present study, mortality in the $18^{\circ} \mathrm{C}$ group was low, increasing by only 11 fish. In parallel, disease severity decreased; in particular, we observed (1) a disappearance of clinical disease signs, (2) a full recovery of normal renal structure, and (3) a significant reduction of the prevalence of infected fish as well as a significant decline of renal parasite loads in infected individuals. The situation was different in the $12{ }^{\circ} \mathrm{C}$ group (Fig. 6). Prevalence of infected fish was 100\%, as in the $18^{\circ} \mathrm{C}$ group. However, the increase of parasite DNA in the kidneys occurred more slowly than at $18^{\circ} \mathrm{C}$ and the maximum level was lower. Cumulative mortality remained low until 47 d p.e., not surpassing $6 \%$. Similarly, clinical disease signs as well as renal histopathology were moderate (Bettge et al. 2009b). After $47 \mathrm{~d}$ p.e., the $12^{\circ} \mathrm{C}$ group displayed a pattern somewhat different from the $18^{\circ} \mathrm{C}$ group. Cumulative mortality remained low, reaching a maximum of $8 \%$. The prevalence of $T$. bryosalmonae-infected fish as well as renal concentrations of parasite DNA continuously decreased, as in the $18^{\circ} \mathrm{C}$ group, but the decrease was slower at $12^{\circ} \mathrm{C}$. In contrast to the $18^{\circ} \mathrm{C}$ group, renal histopathology showed an initial increase in severity until Day 103 p.e. Afterwards, recovery of normal renal morphology was observed. In summary, these findings suggest that individuals surviving the PKD phase associated with maximum clinical signs and maximum mortality are able to 


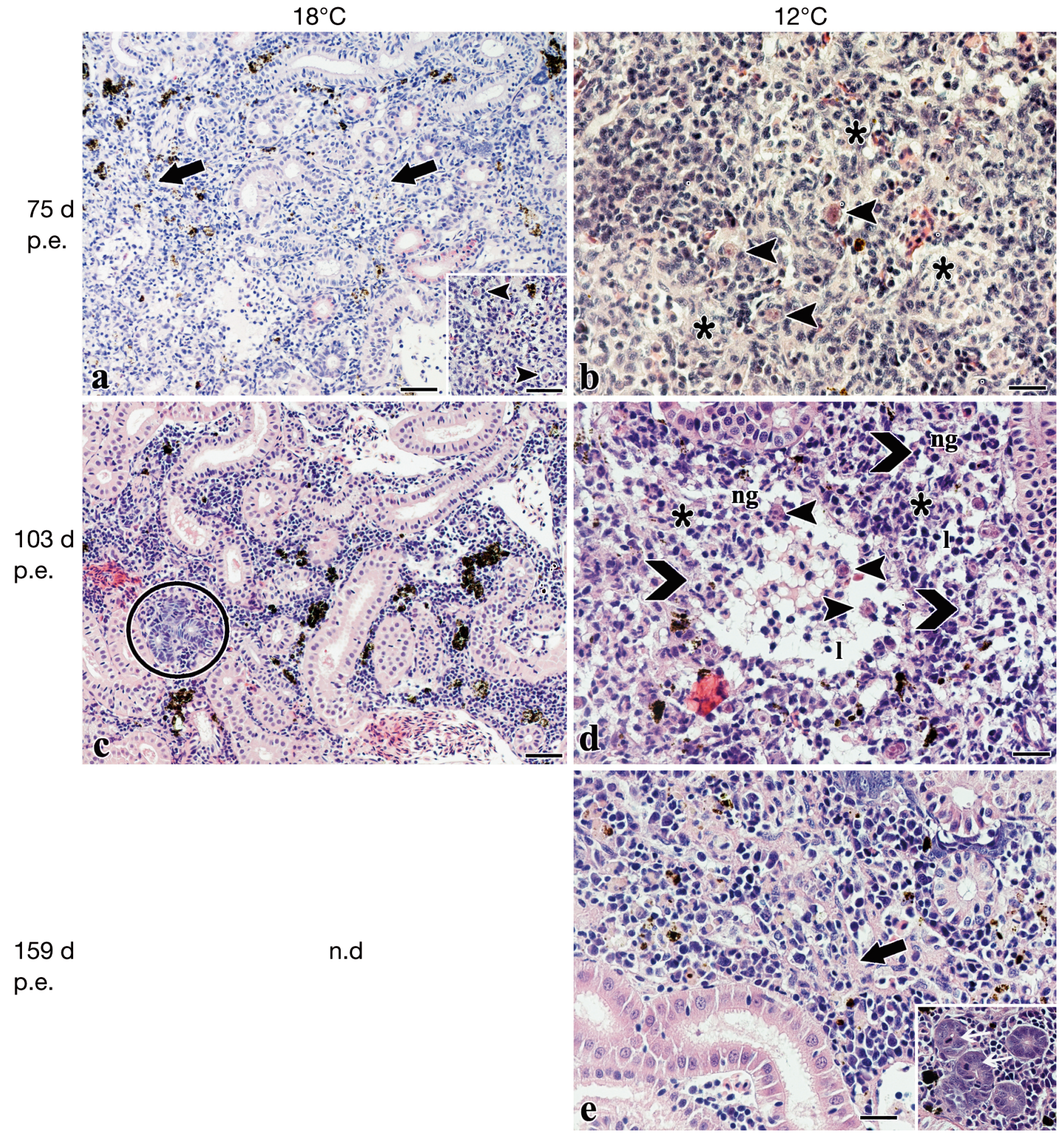

Fig. 5. Tetracapsuloides bryosalmonae in kidneys of rainbow trout Oncorhynchus mykiss, showing histological changes and distribution of parasites in fish held at $18^{\circ} \mathrm{C}$ (left) and at $12^{\circ} \mathrm{C}$ (right) at (a,b) $75 \mathrm{~d},(\mathrm{c}, \mathrm{d}) 103 \mathrm{~d}$ and (e) $159 \mathrm{~d}$ post exposure (p.e.). No fish remained in the $18^{\circ} \mathrm{C}$ group at $159 \mathrm{~d}$ p.e. (n.d.). (a) Small areas with interstitial fibrosis (black arrows); inset shows scattered parasites (arrowheads). (b) Interstitium is expanded as a result of infiltration, mainly by macrophages (*); moderate numbers of parasites (black arrowheads) are also present. (c) Interstitial tissue fully restored, with numerous developing nephrons, characterized by a basophilic cytoplasm and a high nucleus/cytoplasm ratio (inside black circle). (d) Large areas of necrosis (black open arrows) in renal interstitium with fibrin exudation and infiltration with macrophages (*), lymphocytes (l), and neutrophilic granulocytes (nG). Parasites are surrounded by inflammatory cells (arrowheads). (e) Moderate amount of interstitial fibrosis (black arrow); inset shows numerous developing nephrons, characterized by a basophilic cytoplasm and a high nucleus/cytoplasm ratio, and the presence of mitotic figures (white arrows). H\&E staining. Scale bars $=(\mathrm{a}, \mathrm{inset}, \mathrm{c}) 50 \mu \mathrm{m}$, 


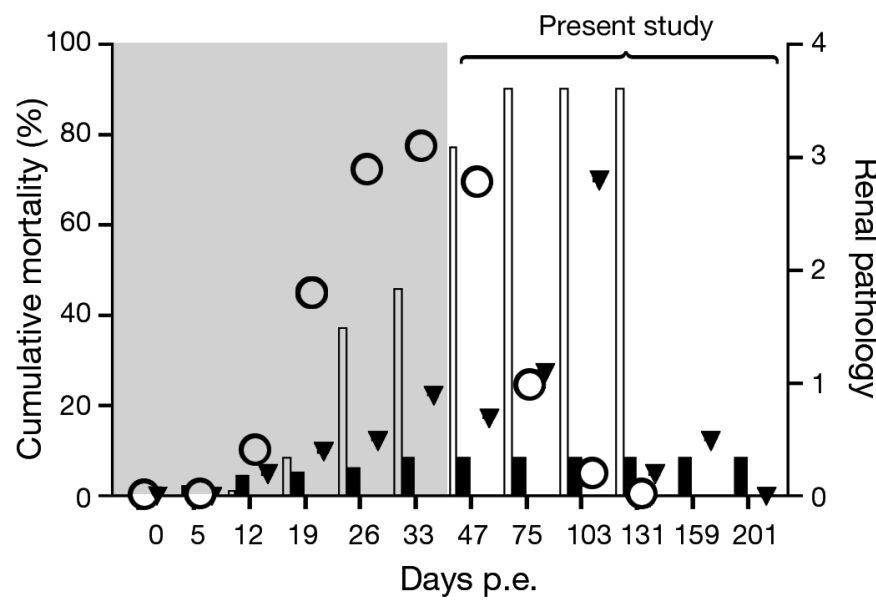

Fig. 6. Development of cumulative mortality (left $y$-axis) and of severity of renal pathology (right $y$-axis) in rainbow trout Oncorhynchus mykiss infected by Tetracapsuloides bryosalmonae, from initial infection until peak of clinical disease at $47 \mathrm{~d}$ post exposure (p.e.) (grey shaded area; see Bettge et al. 2009a) and from Day 47 until the end of the present study $201 \mathrm{~d}$ p.e. Cumulative mortality is given for fish reared at $18^{\circ} \mathrm{C}$ (white bars), and $12^{\circ} \mathrm{C}$ (black bars). Histological changes were semi-quantitatively graded on a scale from 0 to 6 ; the data shown represent mean values for 5 fish of scores based on analysis of the renal interstitium, blood vessels and tubules. Histopathological scores are shown for the $18^{\circ} \mathrm{C}(\mathrm{O})$ and $12^{\circ} \mathrm{C}(\boldsymbol{\nabla})$ treatments

recover, independently of the water temperature. Furthermore, our results indicate a clearance of the parasite from the kidney at high and low water temperatures. Whereas by IHC and ISH almost no parasites were detectable beyond $75 \mathrm{~d}$ p.e. at $18^{\circ} \mathrm{C}$ and $103 \mathrm{~d}$ p.e. at $12^{\circ} \mathrm{C}$, low levels of parasite DNA were still detectable in single animals until the end of the experiment. These results can be explained by methodological differences. Whereas only one section through the kidney tissue can be examined by IHC or ISH, real-time PCR enables investigation of the whole kidney sample. As long as the parasite numbers were below 50 per microscopic field, a good correlation between PCR and IHC/ISH was found, providing evidence to support the reliability of the PCR quantification method. The poor correlation in the $18^{\circ} \mathrm{C}$ group can be explained by the small number of sections examined and the presence of numerous and clustering parasites.

Whether the DNA found at the end of the experiments in single fish of both groups reflects functional parasites, which could cause a new disease outbreak under suitable conditions, has still to be investigated. Both techniques (direct counting and real-time PCR) indicate an accelerated elimination of the parasites at the higher water temperature. This may be due to an influence of temperature on the immune system of the fish, probably affecting the elimination of the parasites by the host (for reviews see Bowden et al. 2007, Bowden 2008, Magnadóttir 2006).

The severity of clinical signs and the associated mortality in Tetracapsuloides bryosalmonae-infected fish were temperature dependent (Bettge et al. 2009a). This has also been shown for other myxozoan parasites, such as Enteromyxum spp. and Myxobolus cerebralis (Yanagida et al. 2006, Murcia et al. 2011). However, whereas histopathological changes also increased with higher water temperature in Мyхоbolus cerebralis-infected cutthroat trout, in the present study only the temporal development of histopathology was accelerated at a higher water temperature. In the present study, the severity of lesions was less influenced by water temperature.

Several studies have shown a regression of renal lesions in rainbow trout surviving the clinical phase of PKD (Ferguson 1981, Kent \& Hedrick 1985, Clifton-Hadley et al. 1987). Fish are able to regenerate renal tissue by repopulation of injured nephrons and, unlike mammals, by the de novo production of nephrons. Renal regeneration by nephron neogenesis has been reported in catfish, rainbow trout, tomcod, zebrafish, tilapia, aglomerular toadfish and medaka (Reimschuessel et al. 1990, 1996, Reimschuessel 2001, Salice et al. 2001, Watanabe et al. 2009, Diep et al. 2011) These nephrons arise from basophilic cell clusters in the interstitium and progress through the normal stages of nephron differentiation. The nephrogenic zone was identified as the region where cell proliferation and mesenchymal cell aggregation is enhanced, and is considered to contain renal stem cell-like mesenchymal cells (Elger et al. 2003). Chilmonczyk et al. (2002) and Morris et al. (2005) reported that a small percentage of animals surviving the clinical phase of PKD still show histopathological lesions up to 27 or $40 \mathrm{wk}$ after infection. In Bettge et al. (2009a) and the present study, in which trout were kept for $28 \mathrm{wk}$ from initial infection and for $22 \mathrm{wk}$ beyond the main clinical phase of the disease, full regeneration of normal renal structure was observed. This indicates that PKD-infected fish can indeed recover from lesions. Importantly, while all aforementioned studies examined kidney regeneration at water temperatures higher than $15^{\circ} \mathrm{C}$, the results from the present study demonstrate that full structural regeneration of kidneys is also possible at lower water temperatures $\left(12^{\circ} \mathrm{C}\right)$. In the natural environment, PKD outbreaks in feral and farmed fish usually occur during summer months, and the recovery process takes place 
towards autumn. Thus, the $12^{\circ} \mathrm{C}$ experiment may well correspond to the recovery condition in freeranging salmonids. Ferguson (1981) found that the recovery process in rainbow trout occured faster at lower water temperatures. In contrast, in zebrafish it has been shown that renal injury, repair and nephron neogenesis is enhanced with increasing water temperature (Reimschuessel \& Ferguson 2006). In the present study, however, the time course of renal regeneration itself seemed to be temperature independent. However, we observed an interesting difference in the process of renal histological regeneration between the 2 temperature groups: in the $12^{\circ} \mathrm{C}$ group, the severity of lesions initially (from 47 to $103 \mathrm{~d}$ p.e.) increased to a level comparable to the intensity in $18^{\circ} \mathrm{C}$ fish at $47 \mathrm{~d}$ p.e., and only afterwards, i.e. beyond Day 103 p.e., a recovery process started. This suggests that the initiation of the recovery process may be triggered by the intensity of the host tissue response, rather than being a function of the duration of infection.

In conclusion, the present study indicates that the severity of renal pathology in PKD-infected rainbow trout is temperature independent whereas the temporal development is temperature dependent with parasite numbers possibly correlating to the time course but not to the severity of lesions (Fig. 6). Moreover, we showed that rainbow trout are able to completely recover from pathological renal lesions caused by an infection with Tetracapsuloides bryosalmonae. In parallel to this, clearance of parasites from the host kidney takes place. Whether the elimination of parasites from the kidney is complete, or viable parasites are still present in the recovered kidneys, remains to be elucidated.

Acknowledgements. We thank the staff of the histology laboratory of the Institute of Animal Pathology for preparation of the histological sections and Ursula Sattler for assisting with real-time PCR. We thank Vanessa Schumacher for English corrections. Additionally, we thank Patricia BurkhardtHolm for fruitful discussions.

\section{LITERATURE CITED}

- Adams A, Richards RH, De Mateo M (1992) Development of monoclonal antibodies to $\mathrm{PK}^{\prime} \mathrm{X}^{\prime}$, the causative agent of proliferative kidney disease. J Fish Dis 15:515-521

Anderson CL, Canning EU, Okamura B (1999) 18S rDNA sequences indicate that PKX organism parasitizes Bryozoa. Bull Eur Assoc Fish Pathol 19:94-97

Bettge K, Wahli T, Segner H, Schmidt-Posthaus H (2009a) Proliferative kidney disease in rainbow trout: time- and temperature-related renal pathology and parasite distribution. Dis Aquat Org 83:67-76
Bettge K, Segner H, Burki R, Schmidt-Posthaus H, Wahli T (2009b) Proliferative kidney disease (PKD) of rainbow trout: temperature- and time-related changes of Tetracapsuloides bryosalmonae DNA in the kidney. Parasitology 136:615-625

Bowden TJ (2008) Modulation of the immune system of fish by their environment. Fish Shellfish Immunol 25: 373-383

Bowden TJ, Thompson KD, Morgan AL, Gratacap RM, Nikoskelainen S (2007) Seasonal variation and the immune response: a fish perspective. Fish Shellfish Immunol 22:695-706

Canning EU, Curry A, Feist SW, Longshaw M, Okamura B (2000) A new class and order of myxozoans to accommodate parasites of bryozoans with ultrastructural observations on Tetracapsula bryosalmonae (PKX organism). J Eukaryot Microbiol 47:456-468

Chilmonczyk S, Monge D, de Kinkelin P (2002) Proliferative kidney disease: cellular aspects of the rainbow trout, Oncorhynchus mykiss (Walbaum), response to parasitic infection. J Fish Dis 25:217-226

Clifton-Hadley RS, Bucke D, Richards RH (1987) A study of the sequential clinical and pathological changes during proliferative kidney disease in rainbow trout, Salmo gairdneri Richardson. J Fish Dis 10:335-352

Curtis BJ, Wood CM (1991) The function of the urinary bladder in vivo in the freshwater rainbow trout. J Exp Biol 155:567-583

Diep CQ, Ma D, Deo RC, Holm TM and others (2011) Identification of adult nephron progenitors capable of kidney regeneration in zebrafish. Nature 470:95-100

Elger M, Hentschel H, Litteral J, Wellner M, Kirsch T, Luft FC, Haller H (2003) Nephrogenesis is induced by partial nephrectomy in the elasmobranch Leucoraja erinacea. J Am Soc Nephrol 14:1506-1518

Feist SW, Bucke D (1993) Proliferative kidney disease in wild salmonids. Fish Res 17:51-58

> Feist SW, Longshaw M, Canning EU, Okamura B (2001) Induction of proliferative kidney disease (PKD) in rainbow trout Oncorhynchus mykiss via the bryozoan Fredericella sultana infected with Tetracapsula bryosalmonae. Dis Aquat Org 45:61-68

$>$ Ferguson HW (1981) Effects of temperature on the development of proliferative kidney disease in rainbow trout, Salmo gairdneri Richardson. J Fish Dis 4:175-177

Grabner DS, El-Matbouli M (2008) Transmission of Tetracapsuloides bryosalmonae (Myxozoa: Malacosporea) to Fredericella sultana (Bryozoa: Phylactolaemata) by various fish species. Dis Aquat Org 79:133-139

$>$ Hedrick RP, MacConnell E, de Kinkelin P (1993) Proliferative kidney disease of salmonid fish. Annu Rev Fish Dis 3: 277-290

> Hedrick RP, Baxa DV, De Kinkelin P, Okamura B (2004) Malacosporean-like spores in the urine of rainbow trout react with antibody and DNA probes to Tetracapsuloides bryosalmonae. Parasitol Res 92:81-88

Hintze J (2006) NCSS, PASS, and GESS. NCSS, Kaysville, UT

Kent ML, Hedrick RP (1985) Development of the PKX myxosporean in rainbow trout Salmo gairdneri. Dis Aquat Org 1:169-182

Longshaw M, Feist SW, Canning EU, Okamura B (1999) First identification of PKX in bryozoans from the United Kingdom-molecular evidence. Bull Eur Assoc Fish Pathol 19:146-148 
Longshaw M, Le Deuff RM, Harris AF, Feist SW (2002) Development of proliferative kidney disease in rainbow trout, Oncorhynchus mykiss (Walbaum), following shortterm exposure to Tetracapsula bryosalmonae infected bryozoans. J Fish Dis 25:443-449

Magnadóttir B (2006) Innate immunity of fish (overview). Fish Shellfish Immunol 20:137-151

Morris DJ, Adams A (2006) Transmission of Tetracapsuloides bryosalmonae (Myxozoa: Malacosporea), the causative organism of salmonid proliferative kidney disease, to the freshwater bryozoan Fredericella sultana. Parasitology 133:701-709

Morris DC, Morris DJ, Adams A (2002) Molecular evidence of release of Tetracapsula bryosalmonae, the causative organism of proliferative kidney disease from infected salmonids into the environment. J Fish Dis 25: 501-504

Morris DJ, Ferguson HW, Adams A (2005) Severe, chronic proliferative kidney disease (PKD) induced in rainbow trout Oncorhynchus mykiss held at a constant $18^{\circ} \mathrm{C}$. Dis Aquat Org 66:221-226

Murcia S, Kerans BL, MacConnell E, Koel TM (2011) Correlation of environmental attributes with histopathology of native Yellowstone cutthroat trout naturally infected with Myxobolus cerebralis. Dis Aquat Org 93:225-234

Okamura B, Anderson CL, Longshaw M, Feist SW, Canning EU (2001) Patterns of occurrence and 18S rDNA sequence variation of PKX (Tetracapsula bryosalmonae), the causative agent of salmonid proliferative kidney disease. J Parasitol 87:379-385

Reimschuessel R (2001) A fish model of renal regeneration and development. ILAR J 42:285-291

Reimschuessel R, Ferguson HW (2006) Kidney. In: Ferguson HW (ed) Systemic pathology of fish. Scotian Press, London, p 91-119

Reimschuessel R, Bennett RO, May EB, Lipsky MM (1990) Development of newly formed nephrons in the goldfish kidney following hexachlorobutadiene-induced nephrotoxicity. Toxicol Pathol 18:32-38

Reimschuessel R, Chamie SJ, Kinnel M (1996) Evaluation of gentamicin-induced nephrotoxicosis in toadfish. J Am Vet Med Assoc 209:137-139

Salice CJ, Rokous JS, Kane AS, Reimschuessel R (2001) New nephron development in goldfish (Carassius auratus) kidneys following repeated gentamicin-induced nephrotoxicosis. Comp Med 51:56-59

> Watanabe N, Kato M, Suzuki N, Inoue C and others (2009) Kidney regeneration through nephron neogenesis in medaka. Dev Growth Differ 51:135-143

- Yanagida T, Sameshima M, Nasu H, Yokoyama H, Ogawa K (2006) Temperature effects on the development of Enteromyxum spp. (Myxozoa) in experimentally infected tiger puffer, Takifugu rubripes (Temminck \& Schlegel). J Fish Dis 29:561-567

Table A1. Comparison of numbers of Tetracapsuloides bryosalmonae in kidneys of rainbow trout Oncorhynchus mykiss kept at 18 and $12^{\circ} \mathrm{C}$, in assessments by immunohistochemical staining (IHC) and in situ hybridization (ISH) in 3 kidney compartments: blood vessels, interstitium and tubules. Numbers in parentheses show lowest and highest values of parasites counted in 6 microscopic fields $(160 \times)$ per fish $(n=5)$ per sample point. Significant differences $(\mathrm{p} \leq 0.05)$ are shown between consecutive samples $\left({ }^{*}\right)$, the 2 methods used on the same samples $(\mathrm{x})$, and the 2 temperature groups at the same sample point and using the same method (y). p.e.: post exposure

\begin{tabular}{|c|c|c|c|c|c|c|c|c|c|c|}
\hline \multirow{2}{*}{$\begin{array}{l}\text { Histological } \\
\text { technique }\end{array}$} & \multicolumn{2}{|c|}{ Day 47} & \multicolumn{2}{|c|}{ Day 75} & \multicolumn{2}{|c|}{ Day 103} & \multicolumn{2}{|c|}{ Day 131} & \multirow{2}{*}{$\begin{array}{c}\text { Day } 201 \\
12^{\circ} \mathrm{C}\end{array}$} & \multirow{2}{*}{$\begin{array}{c}\text { Day } 159 \\
12^{\circ} \mathrm{C}\end{array}$} \\
\hline & $18^{\circ} \mathrm{C}$ & $12^{\circ} \mathrm{C}$ & $18^{\circ} \mathrm{C}$ & $12^{\circ} \mathrm{C}$ & $18^{\circ} \mathrm{C}$ & $12^{\circ} \mathrm{C}$ & $18^{\circ} \mathrm{C}$ & $12^{\circ} \mathrm{C}$ & & \\
\hline \multicolumn{11}{|l|}{ Vessels } \\
\hline $\mathrm{IHC}$ & $\begin{array}{c}4.27 \\
(0-30)\end{array}$ & $\begin{array}{c}0.97 \\
(0-6)\end{array}$ & $\begin{array}{c}0.00^{\mathrm{y}} \\
(0-0)\end{array}$ & $\begin{array}{c}1.27 \\
(0-6)\end{array}$ & $\begin{array}{c}0 \\
(0-0)\end{array}$ & $\begin{array}{c}0.5 \\
(0-3)\end{array}$ & $\begin{array}{c}0 \\
(0-0)\end{array}$ & $\begin{array}{c}0 \\
(0-0)\end{array}$ & $\begin{array}{c}0 \\
(0-0)\end{array}$ & $\begin{array}{c}0 \\
(0-0)\end{array}$ \\
\hline ISH & $\begin{array}{c}4.93 \\
(0-23)\end{array}$ & $\begin{array}{c}1.17 \\
(0-9)\end{array}$ & $\begin{array}{l}0.00^{*} \\
(0-0)\end{array}$ & $\begin{array}{l}0.00^{\mathrm{x}} \\
(0-0)\end{array}$ & $\begin{array}{c}0 \\
(0-0)\end{array}$ & $\begin{array}{c}0.25 \\
(0-2)\end{array}$ & $\begin{array}{c}0 \\
(0-0)\end{array}$ & $\begin{array}{c}0 \\
(0-0)\end{array}$ & $\begin{array}{c}0 \\
(0-0)\end{array}$ & $\begin{array}{c}0 \\
(0-0)\end{array}$ \\
\hline \multicolumn{11}{|l|}{ Interstitium } \\
\hline $\mathrm{IHC}$ & $\begin{array}{c}52.00^{\mathrm{Y}} \\
(0-200)\end{array}$ & $\begin{array}{c}4.87 \\
(0-14)\end{array}$ & $\begin{array}{c}3.80^{*} \\
(0-26)\end{array}$ & $\begin{array}{c}2.53 \\
(0-8)\end{array}$ & $\begin{array}{c}0 \\
(0-0)\end{array}$ & $\begin{array}{c}14.59 \\
(0-63)\end{array}$ & $\begin{array}{c}0 \\
(0-0)\end{array}$ & $\begin{array}{l}0.00^{*} \\
(0-0)\end{array}$ & $\begin{array}{c}0 \\
(0-0)\end{array}$ & $\begin{array}{c}0 \\
(0-0)\end{array}$ \\
\hline ISH & $\begin{array}{c}103.73^{\mathrm{xy}} \\
(1-227)\end{array}$ & $\begin{array}{c}7.4 \\
(1-30)\end{array}$ & $\begin{array}{l}2.00^{*} \\
(0-13)\end{array}$ & $\begin{array}{c}5.33 \\
(0-18)\end{array}$ & $\begin{array}{c}0 \\
(0-0)\end{array}$ & $\begin{array}{l}15.17 \\
(0-76)\end{array}$ & $\begin{array}{c}0.11 \\
(0-1)\end{array}$ & $\begin{array}{l}0.00^{*} \\
(0-0)\end{array}$ & $\begin{array}{c}0 \\
(0-0)\end{array}$ & $\begin{array}{c}0 \\
(0-0)\end{array}$ \\
\hline \multicolumn{11}{|l|}{ Tubules } \\
\hline $\mathrm{IHC}$ & $\begin{array}{c}0.1 \\
(0-1)\end{array}$ & $\begin{array}{c}0.1 \\
(0-2)\end{array}$ & $\begin{array}{l}0.00^{*} \\
(0-0)\end{array}$ & $\begin{array}{c}0 \\
(0-0)\end{array}$ & $\begin{array}{c}0 \\
(0-0)\end{array}$ & $\begin{array}{c}0 \\
(0-0)\end{array}$ & $\begin{array}{c}0 \\
(0-0)\end{array}$ & $\begin{array}{c}0 \\
(0-0)\end{array}$ & $\begin{array}{c}0 \\
(0-0)\end{array}$ & $\begin{array}{c}0 \\
(0-0)\end{array}$ \\
\hline ISH & $\begin{array}{l}0.60^{\mathrm{x}} \\
(0-3)\end{array}$ & $\begin{array}{c}0.07 \\
(0-2)\end{array}$ & $\begin{array}{l}0.00^{*} \\
(0-0)\end{array}$ & $\begin{array}{c}0.07 \\
(0-1)\end{array}$ & $\begin{array}{c}0 \\
(0-0)\end{array}$ & $\begin{array}{c}0.17 \\
(0-2)\end{array}$ & $\begin{array}{c}0 \\
(0-0)\end{array}$ & $\begin{array}{c}0 \\
(0-0)\end{array}$ & $\begin{array}{c}0 \\
(0-0)\end{array}$ & $\begin{array}{c}0 \\
(0-0)\end{array}$ \\
\hline
\end{tabular}


Table A2. Results of histopathological examination of the kidneys of rainbow trout Oncorhynchus mykiss infected by Tetracapsuloides bryosalmonae and held at 18 and $12^{\circ} \mathrm{C}$, showing mean values between 47 and $201 \mathrm{~d}$ post exposure of examined animals ( $\mathrm{n}=5$, if available) and (in parentheses) lowest and highest values, based on the following scoring criteria: (0) no lesions; (1) minimal lesions; (2) mild lesions; (3) mild to moderate lesions; (4) moderate lesions; (5) moderate to severe lesions; (6) severe lesions

\begin{tabular}{|c|c|c|c|c|c|c|c|c|c|c|}
\hline & \multicolumn{2}{|c|}{ Day 47} & \multicolumn{2}{|c|}{ Day 75} & \multicolumn{2}{|c|}{ Day 103} & \multicolumn{2}{|c|}{ Day 131} & \multirow{2}{*}{$\begin{array}{c}\text { Day } 159 \\
12^{\circ} \mathrm{C}\end{array}$} & \multirow{2}{*}{$\begin{array}{c}\text { Day } 201 \\
12^{\circ} \mathrm{C}\end{array}$} \\
\hline & $18^{\circ} \mathrm{C}$ & $12^{\circ} \mathrm{C}$ & $18^{\circ} \mathrm{C}$ & $12^{\circ} \mathrm{C}$ & $18^{\circ} \mathrm{C}$ & $12^{\circ} \mathrm{C}$ & $18^{\circ} \mathrm{C}$ & $12^{\circ} \mathrm{C}$ & & \\
\hline \multicolumn{11}{|l|}{ Interstitium } \\
\hline $\begin{array}{l}\text { Proliferation of hematopoietic } \\
\text { tissue }\end{array}$ & $1(0-2)$ & $3(2-4)$ & $1(0-2)$ & $2(0-4)$ & $0(0-0)$ & $2(2-2)$ & $0(0-0)$ & $0(0-0)$ & $0(0-2)$ & $0(0-0)$ \\
\hline Infiltration & $5(4-6)$ & $2(2-4)$ & $2(0-5)$ & $2(1-4)$ & $0(0-0)$ & $5(3-6)$ & $0(0-0)$ & $0(0-2)$ & $1(0-2)$ & $0(0-0)$ \\
\hline Necrosis & $4(2-6)$ & $2(0-3)$ & $1(0-4)$ & $1(0-2)$ & $0(0-0)$ & $3(2-4)$ & $0(0-0)$ & $0(0-0)$ & $1(0-2)$ & $0(0-0)$ \\
\hline Hemorrhage & $2(0-5)$ & $0(0-0)$ & $1(0-2)$ & $1(0-2)$ & $0(0-0)$ & $2(0-4)$ & $0(0-0)$ & $0(0-0)$ & $0(0-0)$ & $0(0-0)$ \\
\hline Fibrosis & $2(0-3)$ & $0(0-0)$ & $1(0-4)$ & $1(0-2)$ & $0(0-0)$ & $3(2-4)$ & $0(0-0)$ & $1(0-4)$ & $1(0-3)$ & $0(0-0)$ \\
\hline Parasites with daughter cells & $5(1-6)$ & $3(2-4)$ & $1(0-4)$ & $2(0-4)$ & $0(0-0)$ & $3(0-4)$ & $0(0-0)$ & $0(0-0)$ & $0(0-0)$ & $0(0-0)$ \\
\hline Degenerating parasites & $2(0-4)$ & $1(0-2)$ & $1(0-2)$ & $1(0-2)$ & $0(0-0)$ & $2(0-2)$ & $0(0-0)$ & $0(0-0)$ & $0(0-0)$ & $0(0-0)$ \\
\hline \multicolumn{11}{|l|}{ Vessels } \\
\hline Hypertrophy of endothelial cells & $0(0-0)$ & $2(2-2)$ & $1(0-2)$ & $1(0-2)$ & $0(0-0)$ & $2(0-4)$ & $0(0-0)$ & $0(0-0)$ & $0(0-0)$ & $0(0-0)$ \\
\hline Attachment of inflammatory cells & $4(4-4)$ & $4(4-6)$ & $2(0-4)$ & $2(2-4)$ & $0(0-0)$ & $4(2-6)$ & $0(0-0)$ & $0(0-0)$ & $0(0-0)$ & $0(0-0)$ \\
\hline Necrosis of wall of vessels & $4(3-6)$ & $2(0-2)$ & $0(0-0)$ & $1(0-2)$ & $0(0-0)$ & $3(0-4)$ & $0(0-0)$ & $0(0-0)$ & $0(0-0)$ & $0(0-0)$ \\
\hline Thrombi & $4(4-4)$ & $1(0-2)$ & $1(0-2)$ & $1(0-2)$ & $0(0-0)$ & $4(2-4)$ & $0(0-0)$ & $0(0-0)$ & $0(0-0)$ & $0(0-0)$ \\
\hline $\begin{array}{l}\text { Parasites with daughter cells } \\
\text { in lumen }\end{array}$ & $4(1-6)$ & $4(4-6)$ & $1(0-2)$ & $3(1-4)$ & $0(0-0)$ & $2(0-4)$ & $0(0-0)$ & $0(0-0)$ & $0(0-0)$ & $0(0-0)$ \\
\hline \multicolumn{11}{|l|}{ Tubules } \\
\hline Tubulonephrosis & $3(2-4)$ & $1(0-2)$ & $1(0-2)$ & $1(0-4)$ & $0(0-0)$ & $2(2-2)$ & $0(0-0)$ & $0(0-1)$ & $1(0-2)$ & $0(0-0)$ \\
\hline Nephron neogenesis & $0(0-0)$ & $0(0-0)$ & $0(0-0)$ & $0(0-0)$ & $2(2-2)$ & $1(0-2)$ & $0(0-0)$ & $1(0-2)$ & $2(2-3)$ & $0(0-0)$ \\
\hline Intraluminal stages of parasites & $1(0-2)$ & $0(0-0)$ & $0(0-0)$ & $0(0-0)$ & $0(0-0)$ & $0(0-0)$ & $0(0-0)$ & $0(0-0)$ & $0(0-0)$ & $0(0-0)$ \\
\hline
\end{tabular}

Editorial responsibility: Dieter Steinhagen, Hannover, Germany
Submitted: March 21, 2011; Accepted: October 17, 2011 Proofs received from author(s): January 4, 2012 